\title{
SERVICES MARKETING
}




\section{SERVICES MARKETING}

\section{TEXT AND CASES}

Steve Baron

and

Kim Harris 
All rights reserved. No reproduction, copy or transmission of this publication may be made without written permission.

No paragraph of this publication may be reproduced, copied or transmitted save with written permission or in accordance with the provisions of the Copyright, Designs and Patents Act 1988, or under the terms of any licence permitting limited copying issued by the Copyright Licensing Agency, 90 Tottenham Court Road, London W1P 9HE.

Any person who does any unauthorised act in relation to this publication may be liable to criminal prosecution and civil claims for damages.

First published 1995 by

MACMILLAN PRESS LTD

Houndmills, Basingstoke, Hampshire RG21 2XS

and London

Companies and representatives

throughout the world

ISBN 978-0-333-61837-0

ISBN 978-1-349-24174-3 (eBook)

DOI 10.1007/978-1-349-24174-3

A catalogue record for this book is available from the British Library.

$\begin{array}{rrrrrrrrrr}10 & 9 & 8 & 7 & 6 & 5 & 4 & 3 & 2 & 1 \\ 04 & 03 & 02 & 01 & 00 & 99 & 98 & 97 & 96 & 95\end{array}$




\section{Contents}

List of Tables viii

List of Figures $\quad$ ix

Preface $\quad$ x

Acknowledgements $\quad$ xii

1 Introduction $\quad 1$

A 'Service' Experience $\quad 1$

Analysing the Experience $\quad 4$

Our Approach to the Study of Services Marketing $\quad 7$

Characteristics of Case Studies in the Book $\quad 8$

2 Setting the Context $\quad 11$

Introduction $\quad 11$

The Evolution of Services Marketing $\quad 11$

$\begin{array}{ll}\text { Defining and Classifying Services } & 14\end{array}$

The Screen of Service Analysis - A Framework for

Understanding Services Marketing $\quad 18$

$\begin{array}{ll}\text { Summary } & 20\end{array}$

3 The Service Factory $\quad 21$

Introduction $\quad 21$

The Service as a System $\quad 22$

Using the Structure to Understand Services $\quad 25$

Summary $\quad 30$

Case Study 1: Joe and Co, Hairdressing 32

Case Study 2: George Ball and Son, Funeral Directors 38

4 Service Encounters $\quad 48$

Introduction $\quad 48$

Service Encounters as Human Interactions $\quad 50$

Encounters with Other Elements of the Service Environment $\quad 58$

Summary $\quad 59$ 
Case Study 3: G. A. and R. E. Noar and Associates, Dental Practitioners

Case Study 4: Anne Duinkerk, Colour Consultant

5 Service Design

Introduction

Blueprinting

Service Mapping

87

Service Failures and Fail-safing

Pricing

Summary

Case Study 5: Bury Music Service Limited

Case Study 6: An Individual Experience with UK National Health Care

6 Internal Marketing $\quad 126$

$\begin{array}{ll}\text { Introduction } & 126\end{array}$

$\begin{array}{ll}\text { Defining Internal Marketing } & 128\end{array}$

$\begin{array}{ll}\text { Evaluating the Usefulness of the Approach } & 130\end{array}$

Increasing Job Satisfaction of Service Employees $\quad 132$

$\begin{array}{ll}\text { Summary } & 135\end{array}$

Case Study 7: Food Retailing: Maintaining a Competitive Edge with a Quality Approach

Case Study 8: Waymark Holidays

7 Perceived Service Quality and Customer Satisfaction 158

$\begin{array}{ll}\text { Introduction } & 158\end{array}$

How Consumers Assess Service Quality 160

Satisfaction versus Service Quality $\quad 165$

Summary 167

Case Study 9: Expectations of Telephone Banking: The Case of UK Financial Services in the Early 1990s 168

Case Study 10: Johnson Bennett and Co., Chartered Accountants 183

8 Customer Retention and Relationship Marketing 190

$\begin{array}{ll}\text { Introduction } & 190\end{array}$

Defining Relationship Marketing $\quad 192$

Strategies Used to Retain Customers $\quad 195$

$\begin{array}{ll}\text { Summary } & 198\end{array}$

Case Study 11: Søren Madsen, Village Mechanic 200

Case Study 12: The Star FC: Sunday Football Club 204 
9 Service Profitability $\quad 212$

$\begin{array}{ll}\text { Introduction } & 212\end{array}$

Results from the PIMS database $\quad 213$

Quality, Productivity and Profitability Programme 215

$\begin{array}{ll}\text { Loyalty and Profitability } & 217\end{array}$

Statistical Estimations of the Relationships between Profitability,
Customer Satisfaction and Quality

$\begin{array}{ll}\text { Summary } & 225\end{array}$

10 Findings from the Small Business Case Studies 227

$\begin{array}{ll}\text { Introduction } & 227\end{array}$

$\begin{array}{ll}\text { Relevance of Existing Frameworks } & 227\end{array}$

Implications of Case Studies $\quad 227$

Summary 233

11 Further Research Issues and Conclusions 235

$\begin{array}{ll}\text { Introduction } & 235\end{array}$

The Research Agenda $\quad 235$

Future Research in Services Marketing: Some Observations 239

Notes and References $\quad 242$

How the Case Studies Can Be Used 251

$\begin{array}{ll}\text { Index } & 252\end{array}$ 


\section{- List of Tables}

2.1 Classification of service categories

2.2 Services classified according to customisation of service and empowerment of employees

7.1 Staff numbers in major UK banks, 1990

7.2 Profile of respondents

7.3 Expectations by industry sector occupation $\quad 172$

7.4 Antecedents of expectations

7.5 Antecedents of expectations

7.6 Antecedents of expectations

7.7 Antecedents of expectations

174

7.8 Branch banking - determinants of customer expectations

175

7.9 Telephone banking - determinants of customer expectations

175 


\section{List of Figures}

2.1 Scale of marketing entities

2.2 Screen of service analysis (also at the beginning of Chapters 3-9) 19

3.1 The unisex hairdresser as a services marketing system 23

3.2 Range of services offered by Joe and Co 33

4.1 The practice leaflet $\quad 64$

$\begin{array}{ll}5.1 \text { One man gent's barber } & 79\end{array}$

5.2 Multi-staffed unisex hairdresser $\quad 80$

5.3 Blueprint of one-man gent's barber $\quad 82$

5.4 Classification of services according to level of complexity and
degree of divergence.

5.5 Low complexity - high divergence $\quad 84$

5.6 High complexity - low divergence 85

$\begin{array}{ll}5.7 \text { High complexity - high divergence } & 87\end{array}$

5.8 The layers and features of the service map $\quad 88$

5.9 Vertical dimension of a service map 90

5.10 Concept service map $\quad 91$

5.11 Service characteristics by service base, degree of customisation and process evaluation type $\quad 95$

5.12 Map of Bury Metropolitan Borough 98

5.13 Friends of Bury Music Centre $\quad 100$

$\begin{array}{ll}5.14 \text { Scale of fees } & 103\end{array}$

5.15 The services offered 106

5.16 Programme of annual concert at Royal Northern College
of Music

$\begin{array}{ll}5.17 \text { The } 1991 \text { festival programme } & 112\end{array}$

$\begin{array}{ll}5.18 \text { The layout of ward } 3 & 118\end{array}$

6.1 Grading of Waymark Holidays 148

6.2 Extract from The Daily Telegraph, 1 January 1994

6.3 'Waymark News' 154

9.1 Interaction between productivity, quality and profitability 216

$\begin{array}{ll}9.2 \text { Loyalty based system chain } & 220\end{array}$

9.3 Links in the service - profit chain 221

9.4 Return on Quality - chain of effects 224 


\section{Preface}

Service Marketing is a relatively new field, with most of the important contributions to the academic literature being written since the mid-1970s. Prior to the 1980s the marketing of services was normally treated, if at all, as an 'add-on' chapter in marketing texts which were devoted almost entirely to the marketing of goods. However, by the 1990s, the accumulated body of literature and practical cases on the marketing of services has resulted in the elevation of services marketing to an academic subdiscipline in its own right. The interest in, and enthusiasm for, services marketing is a result, in part, of the changing nature of employment in the Western world and the increasing importance of the service sector. In the UK, for example, over 67 per cent of the working population is employed in the service sector.

In keeping with the development of the subdiscipline of services marketing is the recent rapid increase in the number of services marketing courses or units being offered to a variety of audiences. At our own university, for example, Services Marketing is offered as a final year unit to undergraduate Retail Marketing students, as a unit on the MBA course, as a double unit on the Postgraduate Diploma in Marketing Management and as a unit on postgraduate and post-experience courses for middle to senior managers of various retail companies. At other UK universities, undergraduate courses have been developed specifically in Service, or Service Sector, Management for which services marketing is a core unit running over two or three years.

The pioneering textbooks in Services Marketing reflect both the practical nature of the subject through the use of case studies and the multidisciplinary nature of the theoretical underpinnings to the subject, through the use of selected writings originally published in academic journals or specialist texts. Aimed primarily at US audiences, the writings reflect US cultures and issues, and the cases are mainly on large national or multinational services organisations such as telephone companies, airlines or hotel chains. The more recent UK texts have provided a synthesis of the models and theories of Services Marketing (rather than access to the original writings) but have reduced the emphasis on case studies to, at most, one-page snapshots of certain companies. Our own experiences of delivering services marketing units is that student interaction is essential for learning, and that the case study is a very suitable vehicle for such interaction.

Our principal aim, therefore, in writing this book is to explain the issues, models and theories currently recognised as representing the subdiscipline of services marketing, and support this with a bank of original, substantial case studies written from a UK/European perspective. It should, we believe, fit the needs of both the student (in terms of a clear exposition of what is services marketing) and the lecturer (in terms of case studies which can form the basis of discussions, debates and seminars). The material can be covered in a typical semester of twelve to fifteen weeks. We would normally expect, within such a semester, that ten weeks is spent on the key issues in Chapters 2 to 9. The case studies can be used to complement the material in these chapters or to encourage more general idea generation, or debate (see later). 
Most of the case studies in this book are of small service businesses such as hairdressers, dentists, car mechanics and funeral directors. This is a deliberate choice on our part. A (principally) small business focus to the cases is used because:

- they provide the opportunity to demonstrate that services marketing principles and frameworks can be applied to a vast range of commonly used services, as well as to the large services organisations which operate in banking, airports, hotels, restaurants and telephone services;

- it enables us to develop more clearly the people focus and social function of services;

and

- the cases are readily understandable and, we would argue, more interesting and likely to capture attention.

Three of the cases, however, are of a different nature and are written to encourage debate on issues or sectors not fully addressed through a small business perspective. Case Study 6 gives a personalised view of 'service' within a UK National Health Service hospital and should stimulate more general debate on elements of service in the not-for-profit sector. Case Study 9 deals with bank management issues. All the banks in the UK are national, or at least regional, and so a small business approach was inappropriate in this sector. Instead, the case draws attention to an opportunity to rethink the services offered by banks. The issues of internal marketing are more complex, interesting and difficult to manage when considered in the context of larger organizations. Case Study 7 looks, therefore, at some of these issues as expressed publicly by the joint managing director of the UK's largest grocery retailer, J. Sainsbury.

After each case, a number of discussion points are suggested. We have found that most of the cases also allow a more holistic summary of a range of services marketing issues. Case Study 8 'Waymark Holidays', for example, can be studied specifically to examine concepts such as empowerment, as suggested at the end of Chapter 6. Alternatively, we have found that the same case study can be used as a means of generating student examples, which clarify the understanding of the service characteristics of intangibility, inseparability, heterogeneity and perishability. An understanding of such characteristics, and of the managerial implications and possible strategies which result from them, can be achieved more readily through an early focus on a specific case study, coupled with an interactive idea generation session.

The book will be suitable for undergraduate and postgraduate/post-experience students studying services marketing either as a separate unit or as part of a general management or marketing course. It can be read by someone with no prior marketing knowledge, but we recommend that such a reader has access to an introductory mainstream marketing text. A list of references for each chapter is located at the end of the book and provides a basis for further reading for those students wishing to specialise in services marketing or in particular themes within the field. 


\section{Acknowledgements}

We have received tremendous support during the preparation of this book, from many quarters, which has sustained us through the period of writing. We would like to thank Peter Jones and colleagues in the Department of Retailing and Marketing for their encouragement, and for allowing us valuable time and resources. The ambitious task of preparing twelve new case studies could not have been completed without the help of the other contributors - Frank Cassidy, Ole Faaborg, David Quarmby and Anne Yeung - and the cooperation of busy business people whose welcoming attitudes made interviewing a pleasure. To all these people we express our sincere thanks.

We were extremely fortunate to have access to the word processing and desk top publishing skills of Claire Weston, in the first instance, and the team in the 'bungalow' Siobhan Hunter, Ann Marie McDonald and Vera Wasserberg - for the bulk of the work. If ever there was an example of excellent service, this was it, and we are in their debt for meeting the various deadlines. We would like to thank Jane Powell of Macmillan for having confidence in us and offering support and sound advice throughout.

Finally, we thank our 'other halves', Shelagh and Frank, for their encouragement and patience throughout this project.

STEVE BARON

KIM HARRIS

The authors and publishers are grateful to the following for kindly allowing the use of copyright material: American Marketing Association, publishers of the Joumal of Marketing, for Figures 2.1, 5.5, 5.6, and 5.7; MCB Publishers for Figure 5.10; Harvard Business Review for Figure 9.3. Every effort has been made to contact all the copyrightholders, but if any have been inadvertently overlooked the publishers will be pleased to make the necessary arrangement at the earliest opportunity. 